\title{
Teaching Practice of Mathematics Course Based on Innovation Cultivation and Applied Competency of Students in Penetrating Program
}

\author{
Xuemei Yu \\ Beijing Polytechnic \\ Beijing, 100176 China
}

\begin{abstract}
The national key measures for cultivating top technical-skilled talents came into being just as the times' requirements. In recent years, Beijing has taken the lead in introducing the " $2+3+2 "$ penetrating cultivation program as a new education and cultivation mode. The cultivation of classroom teaching and applied innovative competency in the basic stage of penetrating cultivation attracts particular importance. How to teach, what to teach, how to carry out and implement teaching activities effectively, as well as how to combine classroom teaching with practical application issues have become the key issues for colleges and universities undertaking this program. This paper takes the mathematics course of penetrating program as a carrier, and has the cultivation of innovative application competency based on educational practice activities throughout the whole process of teaching, so as to cultivate students' comprehensive competency in innovative practical application for the purpose of cultivating top technical-skilled personnel.
\end{abstract}

Keywords-penetrating program; innovative application competency; mathematics course; teaching practice

\section{INTRODUCTION}

With economic development and scientific progress, professional posts centered on high-tech applications have shown richer and richer requirements, and the development level of vocational education can be different in different countries due to the difference in social economy and scientific development degree. At present, there are six popular international education modes in the cultivation of applied talents.

TABlE I Six Kinds of Cultivation \& TRaining Modes of APplied Talents

\begin{tabular}{|c|c|c|c|}
\hline Name of training mode & Specific contents & Representative countries & Main characteristics and deficiencies \\
\hline (1) CBE mode & $\begin{array}{l}\text { Competency-based education, aims at } \\
\text { cultivating all competencies of students } \\
\text { necessary for vocational posts. The core is to } \\
\text { determine the comprehensive and special } \\
\text { competencies of talents needed for vocational } \\
\text { posts from the needs of posts, and then design } \\
\text { the teaching content system, formulate } \\
\text { relevant competency analysis forms, organize } \\
\text { teaching content, and finally assess whether } \\
\text { competency requirements are met. }\end{array}$ & $\begin{array}{l}\text { The United States } \\
\text { Canada }\end{array}$ & $\begin{array}{l}\text { CBE mode breaks the teaching mode based on } \\
\text { traditional public course and basic course, } \\
\text { emphasizing the vocational competency cultivation } \\
\text { required by the post as the core, thus ensuring the } \\
\text { realization of the goal of competency training. } \\
\text { However, CBE mode is more targeted but relatively } \\
\text { narrow in vocation and highly focuses on the } \\
\text { cultivation of practical skills, which is not conducive } \\
\text { to sustainable development because of its relatively } \\
\text { small grasp of basic knowledge and theory. }\end{array}$ \\
\hline 2) CBET mode & $\begin{array}{l}\text { Competency-based education and training } \\
\text { refers to the education and training based on } \\
\text { competency. The key link of CBET mode is } \\
\text { to organize experts to determine competency } \\
\text { standards, set up national qualification } \\
\text { committee, establish competency-based } \\
\text { national vocational qualification certificate } \\
\text { system, and combine talent training mode } \\
\text { with system. It is the institutionalization of } \\
\text { talent training mode. }\end{array}$ & $\begin{array}{l}\text { UK } \\
\text { Australia }\end{array}$ & $\begin{array}{l}\text { The advantage of CBET mode lies in the } \\
\text { establishment of national general professional } \\
\text { qualification certificate by defining competency } \\
\text { standards, reflecting a strong flexibility and } \\
\text { openness in the recognition of learning outcomes, } \\
\text { and enhancing the general recognition and } \\
\text { confidence of the public and industries in national } \\
\text { certificate. } \\
\text { Australia has also created a "training package" that } \\
\text { combines recognized standards, outlines, training } \\
\text { assessments and qualifications for skills recognition } \\
\text { to meet the training needs of one or more industries } \\
\text { from the perspective of industry. }\end{array}$ \\
\hline
\end{tabular}


Table I, cont

\begin{tabular}{|c|c|c|c|}
\hline (3) Dual-system mode & $\begin{array}{l}\text { Dual-system mode is that enterprises and } \\
\text { schools share the task of cultivating talents, } \\
\text { and organize teaching and post training } \\
\text { according to the requirements of talent } \\
\text { cultivation objectives. }\end{array}$ & Germany & $\begin{array}{l}\text { 1) Closely integrated with production } \\
\text { Students stay in enterprises most of the time to } \\
\text { participate in skills training for practical operation } \\
\text { with equipment and technology currently used by } \\
\text { enterprises, and are trained in the way of productive } \\
\text { labor, which improves the purpose of learning and } \\
\text { indirectly reduces the cost. It is very beneficial for } \\
\text { students to be engaged in work immediately after } \\
\text { training. } \\
\text { 2) Extensive participation of enterprises } \\
\text { Most mature enterprises have their own training } \\
\text { personnel and training bases. Some small and } \\
\text { medium-sized enterprises that are unable to provide } \\
\text { comprehensive and diversified vocational training } \\
\text { alone can also participate in vocational education } \\
\text { through cross-enterprise cooperation and } \\
\text { supplementary training of schools and factories. } \\
\text { 3) Interconnection of various forms of education } \\
\text { This is also the most remarkable feature. All forms } \\
\text { of education are diverted at any time. At every stage } \\
\text { after basic education, they can be transferred from } \\
\text { ordinary schools to vocational schools; Students } \\
\text { who receive dual-system vocational training can also } \\
\text { enter colleges and universities to study after taking } \\
\text { cultural courses. }\end{array}$ \\
\hline (4) STW mode & $\begin{array}{l}\text { School to Work, namely, from school to } \\
\text { work. It refers to the process of transition } \\
\text { from full-time school learning or related } \\
\text { equivalent activities as the main task to full- } \\
\text { time work for young people, or from full-time } \\
\text { learning to full-time work for young students. }\end{array}$ & $\begin{array}{l}\text { The United States } \\
\text { UK } \\
\text { Australia } \\
\text { Japan }\end{array}$ & $\begin{array}{l}\text { The actual situation of each country is different, so } \\
\text { it has its own characteristics in route selection, } \\
\text { policy and strategy support. }\end{array}$ \\
\hline (5) TAFE mode & $\begin{array}{l}\text { It is a multi-level, flexible and comprehensive } \\
\text { talent training mode, which is driven by } \\
\text { industry, integrated by government, industry } \\
\text { and school, effectively linking up with and } \\
\text { relatively independent of secondary schools } \\
\text { and universities. }\end{array}$ & Australia & \\
\hline $\begin{array}{l}\text { (6) Modern apprenticeship } \\
\text { mode }\end{array}$ & $\begin{array}{l}\text { Modern apprenticeship, MA. It is a way of } \\
\text { skill training, which is similar to the full-time } \\
\text { education school mode in form. }\end{array}$ & $\begin{array}{l}\text { UK } \\
\text { Australia }\end{array}$ & $\begin{array}{l}\text { It is characterized by on-the-job training. Students } \\
\text { can earn a certain amount of income while learning. } \\
\text { Training is closely linked with employers, helping } \\
\text { young people newly entering the labor market to } \\
\text { learn skills while looking for employers, helping } \\
\text { young people who have lost their learning } \\
\text { opportunities to create learning opportunities. } \\
\text { Integration with national vocational qualification } \\
\text { certificates encourages them to have the competency } \\
\text { to learn for the whole life. }\end{array}$ \\
\hline
\end{tabular}

In recent years, some higher vocational colleges in Beijing have cooperated with demonstration high schools and undergraduate colleges to undertake the " $2+3+2 "$ high-end technical and skilled personnel penetrating cultivation program launched by Beijing. For seven-year penetrating cultivation, junior high school graduates take two-year basic stage courses to study at higher vocational colleges, choose the professional direction after two years to enter the higher vocational stage to continue learning for three years, and carry out the study of professional foundation, technical theory and core skills. In the basic stage, basic science, humanities and art are taken as the main line, consolidating the cultural foundation and broadening the cultural horizon. As a basic subject, it is not restricted by the college entrance examination, which is different from the ordinary high school teaching mode, but focuses on cultivating students' scientific literacy, professional literacy and innovative spirit. Therefore, it is of great significance to the teaching and implementation of the basic courses for students in the penetrating cultivation program.

Mathematics is an important basic subject in the penetrating cultivation program. There are some characteristics and corresponding problems in the teaching of basic stage in the first two years of the penetrating cultivation program. For the students of penetrating program who have their own unique cognitive mode and acceptance competency, it is necessary to supplement the abstraction of traditional mathematics teaching and insufficient connection with actual life application of students, but also combine theory with practice closely, which is a good way to cultivate students' application and innovative competency. For example, the infiltration of mathematical 
modeling thought and the development of corresponding courses can make students experience the close connection between mathematics and practical application, and combine theory with practice organically.

\section{RESEARCH SIGNIFICANCE}

In today's society, creative and innovative competency will be the key factor determining a person's destiny and future. Mathematics is not only an important subject in the field of natural science, but also closely related to economics, sociology and other fields. Mathematics learning is no longer just about memorizing knowledge, familiarizing with definitions and understanding theorems, emphasizing the promotion of application and innovative competency, in addition to the cultivation of logic and abstract competency. Improving the application and innovation competence of students in the basic stage teaching of mathematics of penetrating program can enhance students' interest in learning, stimulate their enthusiasm for learning, help students correctly understand the development direction of mathematics, and also provide important thinking methods and research ways, which conforms to the penetrating cultivation objectives of high-end technical and skilled personnel, and plays a role in students' major selection, work, study and life.

Mathematics knowledge learning is an indispensable condition for the formation and development of students' innovation competency. To talk about innovative competency separately from the study of knowledge and skills is to neglect the essentials. It is necessary to clearly recognize that the acquisition of skills is not equal to the formation and development of competency. The innovative personality characteristics of students in teaching are mainly manifested in: interest and self-confidence, curiosity and exploration desire, tenacious will and perseverance, and the spirit of doubting everything. That is to say, innovative personality characteristics are the key to cultivate students' innovative competency. Therefore, the basic stage mathematics teaching of penetrating cultivation should let students experience innovation and learn innovation in the acquisition and construction of knowledge, practice innovation and learn innovation in the application of knowledge.

\section{PRACTICE OF CULTIVATING APPLIED INNOVATIVE COMPETENCY BASED ON COURSE TEACHING}

Combining with teaching practice and theoretical exploration of innovative competency, this paper carries out the study and practice of the cultivation of students applied innovative competency in the teaching of penetrating program mathematics course, and puts forward the following implementation methods and strategies.

\section{A. Induce innovation: Modular decomposition, rich structure}

The formation of mathematical knowledge should go through the process of occurrence, development and deepening. The current situation of students' thinking should be understood in the teaching implementation on the premise of students' existing knowledge and experience level. Main teaching methods: 1. Establish a scenario and create a harmonious and democratic teaching situation; 2. Optimize the structure, infiltrate the mathematics thinking method, form a good cognitive structure, improve the comprehensive competency of generalization and analysis, and experience the new mathematics thinking method in the process of putting forward and developing problems. 3. Invigorate the beauty and innovation, letting students feel the beauty of mathematics, experience the beauty of mathematics and appreciate the beauty of mathematics in the process of knowledge exploration and development. 4. Enhance cognition, showing teachers' thinking process at appropriate time, exposing students' thinking to delay judgment properly, leaving students sufficient time for thinking and discussion.

\section{B. Exploration and innovation: Method renewal and open teaching}

Generally speaking, most of the teaching contents are closed questions, which are based on certain logical relations to find the only correct answer. In order to cultivate innovative competency, traditional mathematical problems should be changed into open problems according to the teaching content and teaching situation, which can be opened with the known conditions. The open problems of strategy can be opened with the conclusions, or can be research-based study problems extending outside the classroom.

\section{Exploration and innovation: Various modes, research- based study}

Mathematics research-based study mainly organizes students' study activities around raising and solving problems. It mainly carries out research-based learning of mathematics in the basic stage of the penetrating program from three aspects: 1 . Experimental teaching. It is to keep students in the state of participating, exploring and seeking knowledge to experience research-based learning, and cultivates the consciousness and competency of discovering and independently exploring problems. 2. Extension and innovation. whether intuitive insight is sensitive, and whether thinking is flexible or smooth are indispensable factors for extension and innovation. Students should be encouraged to question and guess boldly, because accidental perception can also produce innovation. 3 . Experience life. The teaching process is not necessarily carried out in the classroom. It can be anywhere, with any contents. It is important to provide students with rich channels to discover and gain practical experience, to help them understand the real society, to experience the process of discovering and solving problems, and to enhance their practical and innovative competencies.

\section{Practical innovation: Use technology, provide platform}

Applied mathematics is the main purpose of mathematics learning. With the rapid development of society, the popularization of high-end calculators, computers and various mathematical software, students' learning process has also been greatly affected. The application of teaching methods can make students fully realize the importance of mathematical technology, and the product of mathematical application is mathematical technology. Their functions can make the application truly and effectively integrated with students' learning, thus establishing correct mathematical consciousness. Mathematics application involves various fields. Teachers can provide students with an open and multi-level innovative practice platform in the process of teaching, enrich knowledge 
in various fields by using various resources, and cultivate students' innovative consciousness and practical competency.

\section{REFLECTIONS ON CULTIVATING APPLIED INNOVATIVE COMPETENCY BASED ON COURSE TEACHING}

\section{A. Teachers' ideas should be changed}

Teachers play the main role in the classroom in the traditional concept, with a high degree of authority, which is not conducive to the cultivation of students' competency to innovate and apply. In the process of teaching, it is not desirable to only pay attention to the imparting of mathematical knowledge, but to emphasize the logical thinking competency of operation. It is a gradual process to cultivate students' innovative spirit. The differences among students exist objectively. It is required to patiently provide every student with the opportunity to boldly question and practice innovation in the teaching process. In the implementation of curriculum teaching, it is emphasized that students' autonomous activities are not equal to completely free activities. The scale should be grasped and tradition should be combined with innovation.

\section{B. Teaching methods should be renewed}

In the process of teaching, there is no only correct teaching mode. It is necessary to cultivate students' innovative competency and advocate diversification of teaching modes. For example, stratified teaching, combination of classroom and extracurricular practice, group discussion and so on. Various teaching modes complement each other to cultivate students' innovative competency and promote students' all-round development. The classroom teaching should strengthen the application consciousness, guide students to learn, adopt discussion-based and cooperation-based teaching, promote research-based teaching through comprehensive practice, and improve students' innovative competency through multi-level practice.

\section{Assessment and evaluation should be diversified}

In the process of teaching, assessment is an important link. Teachers should establish scientific and innovative evaluation concepts, combine in-class performance and after-class practice with online evaluation, distinguish the proportion of summative evaluation and process evaluation, and combine relativeness and absoluteness. The purpose of evaluating students' learning is to motivate them, teach them in accordance with their aptitude, and give them timely affirmation based on the principle of encouragement, so as to stimulate their learning enthusiasm and desire for knowledge.

\section{CONCLUSION}

Under the mode of penetrating cultivation education, it is the demand of development to cultivate students' applied innovative competency in the teaching of mathematics course at the stage of basic education, and it is also the only way to cultivate highend technical skilled talents in the teaching reform. Starting from the cultivating objectives and students' own needs, how to use curriculum teaching to cultivate students' applied innovative competency is the issue worth thinking about for the front-line teachers of the teaching at the basic stage of penetrating program. It is required to constantly accumulate experience, reflect on it in time, integrate the goal of program reform with the realization of curriculum teaching, implement the educational idea of "cultivating high-end, excellent and top-notch students", and cultivate students' applied innovative competency through it, so as to realize the teaching reform of quality education scientifically and effectively.

\section{ACKNOWLEDGMENT}

About the author: Xuemei YU, (1988-), female, graduate student, lecturer of Beijing Polytechnic.

\section{REFERENCES}

[1] Xuejun HAN. Cultivation of applied innovative talents and construction of vocational higher education system. China Renmin University Press. 2010

[2] Peilian YAN. High School Mathematics Classroom Teaching and Students' Innovative Competency. Graduation Thesis of Master of Education of Northwest Normal University 2002.

[3] Shengchao LIU. Research on the Cultivation of Students' Innovative competency and Applied competency in High School Mathematics Teaching. Master's Thesis of Hunan Normal University. 2011.

[4] Jiafeng LIANG. Consideration and Practice of "2+3+2" High-end Technical Skilled Talents Penetrating Cultivation [J]. Beijing Education, September 2015.

[5] Xuemei YU. Significance of Infiltrating Modeling Thought into Penetrating Program Mathematics Teaching [J]. Mathematics Learning and Research, December 2017.

[6] Xuemei YU. Teaching Practice of Cultivating Students' Innovative Competency of Penetrating Program Based on Mathematical Modeling Course [J]. Education Modernization, January 2018. 